\title{
Thermal Expansion of Triaxially Stressed Mudstone at Elevated Temperatures up to $400^{\circ} \mathrm{C}$
}

\author{
Zi-jun Feng $\mathbb{D}^{1,2}$ Meng-meng Qiao, ${ }^{1,2}$ Fu-ke Dong, ${ }^{2,3}$ Dong Yang, ${ }^{2}$ and Peng Zhao ${ }^{1,2}$ \\ ${ }^{1}$ Department of Mining Engineering, Taiyuan University of Technology, Taiyuan, Shanxi 030024, China \\ ${ }^{2}$ Key Laboratory of In-Situ Property-Improving Mining of Ministry of Education, Taiyuan University of Technology, Taiyuan, \\ Shanxi 030024, China \\ ${ }^{3}$ Department of Geology, Hebei Vocational College of Geology, Shijiazhuang, Hebei 050081, China
}

Correspondence should be addressed to Zi-jun Feng; fengzijun@tyut.edu.cn

Received 6 February 2020; Revised 29 May 2020; Accepted 15 July 2020; Published 8 August 2020

Academic Editor: Francesco Ruffino

Copyright (C) $2020 \mathrm{Zi}$-jun Feng et al. This is an open access article distributed under the Creative Commons Attribution License, which permits unrestricted use, distribution, and reproduction in any medium, provided the original work is properly cited.

\begin{abstract}
In order to study the thermal deformation of the rock that surrounds underground engineering projects with elevated temperatures (e.g., underground coal gasification, coal in situ pyrolysis, in situ oil and gas extraction from oil shale, geothermal energy extraction from rock, among others), a servocontrolled machine (model IMT-HTP 100F) was used to examine the thermal expansion of triaxially stressed mudstone at temperature up to $400^{\circ} \mathrm{C}$. Two distinct stages of thermal expansion were found at temperatures up to $400^{\circ} \mathrm{C}$ : very small thermal expansion below $50^{\circ} \mathrm{C}$, followed by almost constant thermal expansion at $50-400^{\circ} \mathrm{C}$. This linear thermal expansion coefficient of triaxially stressed mudstone did not increase in the range $50-400^{\circ} \mathrm{C}$. The effect of the applied triaxial stress was on both close cracks and impeded grain expansion and the swelling of the rock. Mudstone had a larger linear thermal expansion coefficient than either sandstone or limestone, in that order. The potential energy theory was used to explain the intrinsic variation of thermal expansion of the different rock types.
\end{abstract}

\section{Introduction}

The mudstone stratum is typical of geological strata containing oil, gas, coal, and other hydrocarbon resources. The variation in the thermal properties of mudstone is of importance for safe mining in underground coal gasification, coal in situ pyrolysis, and in situ oil and gas extraction from oil shale. The mudstone stratum is generally located at the top and/or bottom of these reservoirs. Hence, in such underground engineering projects, high temperature and high heating rate may lead to thermal damage of the reservoir rocks [1-8]. In addition, the mudstone stratum is subjected to high temperatures and triaxial ground stresses. The thermal deformation of mudstone strata has a significant impact on the movement of the whole geological formation $[2,9,10]$ and is likely to cause inflows of water from upper aquifers in a high-temperature work face [11].

Early studies of thermal expansion of rock were performed on rock specimens (mainly lunar rock and igneous rocks) in unconstrained conditions. To determine the effect of the lunar environment on damage to lunar rock, an experimental study [12] investigated the effect of reduced pressure on the thermal expansion of simulated lunar materials. They found that thermal expansion and the response of simulated lunar rock material to induced thermal stresses were independent of environmental pressure [12]. Subsequent experiments on thermal expansion of several igneous rocks found that it was a function of crack porosity, heating rate, maximum temperature, mineralogical composition, and preferred crystal orientation [13-19].

The thermal expansion coefficient of bulk rock at atmospheric pressure and temperatures up to $400^{\circ} \mathrm{C}$ increased more rapidly as temperature increased than the average thermal expansion coefficient of the constituent minerals. For example, the volumetric coefficient of thermal expansion of Graniteville granite (Missouri, USA) increased from $10^{-5 \circ} \mathrm{C}^{-1}$ at room temperature to about $7.8 \times 10^{-5 \circ} \mathrm{C}^{-1}$ at $400^{\circ} \mathrm{C}$, whereas the value for constituent minerals such as 
plagioclase increased from $1.3 \times 10^{-5 \circ} \mathrm{C}^{-1}$ at room temperature to approximately $1.8 \times 10^{-5 \circ} \mathrm{C}^{-1}$ at $400^{\circ} \mathrm{C}$. The "extra" expansion was attributed to thermally induced cracks due to the differential expansion of mineral grains [12-14]. High heating rates of $5^{\circ} \mathrm{C} \cdot \mathrm{min}^{-1}$ resulted in higher thermal expansion than lower heating rates of $2^{\circ} \mathrm{C} \cdot \mathrm{min}^{-1}$. The most important conclusion was that a low heating rate (no greater than $2^{\circ} \mathrm{C} \cdot \mathrm{min}^{-1}$ ) avoids thermal gradient cracking in rock $[12,13,16-18,20-23]$. The coefficient of thermal expansion was a function of both temperature and the maximum temperature to which the rock had been exposed. Permanent thermal strain was associated with maximum temperatures of cycling $[14,15,20]$.

Experimental rock thermal expansion has been performed under uniaxial stress. In order to reflect the actual in situ stress state to which rocks are subjected, tests were carried out on granite, sandstone, and limestone. Uniaxial compression tests conducted on granite under real-time high temperature found an exponential relationship between the thermal expansion coefficient and temperature [24]. A study of the thermal expansion behavior of granite and sandstone under uniaxial stress conditions [25] found that the thermal expansion coefficient of all granite samples was quite similar during heating up to $1000^{\circ} \mathrm{C}$. It was also similar for sandstone samples $[25,26]$, although the $\alpha / \beta$ transition of quartz had a significant effect on thermal cracking [27]. A study of the variation of thermal expansion coefficient of sandstone at different high temperatures [28] found that the sandstone exhibited four stages of thermal expansion. A study of mudstone [29] found that the thermal strain and expansion coefficient increased with increasing temperature. They explained that the main reason for the thermal expansion was the variation of internal pores and cracks as well as the thermochemical effects of mineral components. Measurement of the thermal expansion of oil shale under various compressive loads showed that increasing the compressive load reduced the maximum expansion [30, 31].

Very few studies have focused on the thermal expansion of triaxially compressed rock due to the limitations of experimental technology. Our previous works have studied the thermal expansion of coal and granite subjected to triaxial compression. The thermal deformation of coal occurs in three phases: thermal expansion from room temperature (RT) to $200^{\circ} \mathrm{C}$, slight compression (bulk strain $1.1 \times 10^{-3}$ ) at $200-400^{\circ} \mathrm{C}$, and strong compression (bulk strain $50 \times 10^{-3}$ ) at $400-600^{\circ} \mathrm{C}$. The critical temperature of transition from thermal expansion to compression is $200^{\circ} \mathrm{C}$ due to the start of pyrolysis $[32,33]$. Thermal deformation of granite occurs in three stages: slight deformation at low temperatures (RT to $120^{\circ} \mathrm{C}$ ) with a relatively low thermal expansion coefficient; a rapid deformation period at medium-high temperatures $\left(120-450^{\circ} \mathrm{C}\right)$, during which the thermal expansion coefficient increases nonlinearly with increasing temperature; and slight deformation at high temperatures $\left(450-600^{\circ} \mathrm{C}\right)$, during which time the thermal expansion coefficient decreases dramatically with increasing temperature. The thermal expansion coefficient is approximately 20 times less than the coefficient without confinement $[34,35]$. The coefficient of thermal expansion of water-saturated igneous rocks and limestone were also observed to increase with increasing temperature at all pressures [36, 37]. Very significant thermal expansion anisotropy was found in quartz at temperatures up to $180^{\circ} \mathrm{C}$ [20]. Obvious anisotropy of thermal expansion has also been reported for coarse-grained marble at $20-200^{\circ} \mathrm{C}$ [38].

Extensive work has focused on the thermal expansion of unconstrained and uniaxially compressed granite, sandstone, limestone, and marble, generally subjected to threedimensional ground stresses in underground high-temperature engineering cases such as underground coal gasification, coal in situ pyrolysis, and in situ extraction of oil and gas from oil shale. Because mudstone is also commonly found in geo-energy and geo-resources geological formations, in this study, we performed a series of experiments on mudstone overlying oil shale to measure the thermal expansion when triaxially confined and at temperatures up to $400^{\circ} \mathrm{C}$.

\section{Experimental Procedures}

2.1. Samples. Mudstone blocks were collected from the roof strata of an oil shale deposit in an open pit mine in Jimsar, Xinjiang. All weathered material to ensure that fresh mudstone blocks were used. Standard-size samples $50 \mathrm{~mm}$ diameter and $100 \mathrm{~mm}$ long, shown in Figure 1, were prepared in the laboratory. The constituent minerals as obtained by X-ray diffraction were quartz (57\%), plagioclase (10\%), siderite (4\%), and clay minerals (29\%). The clay minerals were mainly illite/smectite (82\%), illite (9\%), kaolinite (8\%), and chlorite $(1 \%)$.

2.2. Experimental Setup and Procedures. A servocontrolled high temperature test machine for rock mechanics (IMTHTP 100F), developed by the authors, was used to measure the thermal expansion of the mudstone (Figure 2(a)). This was designed to measure the real-time physical and mechanical properties of rock subjected to triaxial stresses and high temperature up to $600^{\circ} \mathrm{C}$.

Inert gas or heat-transfer oil may be used in this apparatus as the confining medium around the sample. In these experiments, heat-transfer oil was used. Each sample was jacketed in a red copper sleeve designed by the authors. Heat-transfer oil confining pressure up to $70 \mathrm{MPa}$ was applied to the sample by a pump. Axial pressure up to $500 \mathrm{MPa}$ was applied to the sample by a piston. The sample was heated to $600^{\circ} \mathrm{C}$ by electrically heated rods. The controlled heating rate could be varied from 0.04 to $10^{\circ} \mathrm{C} \cdot \mathrm{min}^{-1}$. The granite sample was calibrated, giving a thermal gradient of approximately $0.167^{\circ} \mathrm{C} \cdot \mathrm{mm}^{-1}$ throughout the sample at a heating rate of about $10^{\circ} \mathrm{C} \cdot \mathrm{hr}^{-1}$. Therefore, this rate was adopted to obtain a relatively equilibrated temperature distribution inside the test specimen during heating. The displacement rate of the axial piston was variable from $10^{-2}$ to $10^{4} \mu \mathrm{m} \cdot \mathrm{s}^{-1}$. The maximum duration of maintaining a constant high temperature was more than $720 \mathrm{~h}$.

In this experiment, the mudstone specimens were encased in the red copper jackets and placed in the vessel 


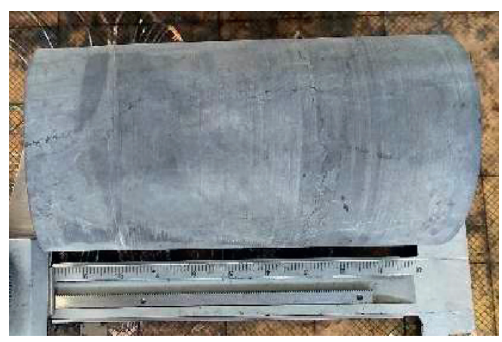

Figure 1: Mudstone test specimen.

(Figure 2(b)). Quartz cylinders (very low thermal expansion, $\sim 10^{-7} .{ }^{\circ} \mathrm{C}^{-1}$ ) were positioned between each end of the test specimen and the platen and piston of the testing machine. The piston was cooled by cycling water.

In the experiment, two groups of stress state were simulated. In the first group, axial stress of $5 \mathrm{MPa}$ and confining pressure of $6 \mathrm{MPa}$ were applied to the specimen (considering 1.2 as lateral coefficient). This stress state is equivalent to an in situ rock stress at $200 \mathrm{~m}$ depth.

The second group, with a high ratio of axial-to-confining stress, was designed to study the stress effect on thermal expansion. This group had two subgroups: (1) axial stress $12 \mathrm{MPa}$ and confining pressure $6 \mathrm{MPa}$; (2) axial stress $8 \mathrm{MPa}$ and confining pressure $4 \mathrm{MPa}$. A low heating rate of $10^{\circ} \mathrm{C} \cdot \mathrm{hr}^{-1}$, shown in Figure 3, was used to eliminate thermal shock in the test specimens. The target temperature was $400^{\circ} \mathrm{C}$, except for sample $2^{\#}$, which was heated only to $300^{\circ} \mathrm{C}$ due to a power outage in the laboratory. The detailed testing conditions for all samples are listed in Table 1.

\section{Results and Discussion}

3.1. Effect of Temperature on Thermal Deformation of Triaxially Stressed Mudstone. The sign convention in rock mechanics is that compressive deformation is positive, and expansive (tensile) deformation is negative. Figure 4 shows the measured axial strain of mudstone samples from room temperature to $400^{\circ} \mathrm{C}$. The compressive axial strain in samples under triaxial stresses in Figure 4 is, therefore, negative. The thermal strain in sample $1^{\#}$ from zero at room temperature $\left(\sim 10^{\circ} \mathrm{C}\right)$ to $4 \times 10^{-5}$ at $21^{\circ} \mathrm{C}$ was followed by a linear increase to 0.01 at $395^{\circ} \mathrm{C}$. The same trend was evident in sample $2^{\#}$. Thermal strain of sample $2^{\#}$ increased from zero at room temperature to $6 \times 10^{-5}$ at $50^{\circ} \mathrm{C}$, then increased linearly to 0.00885 at $300^{\circ} \mathrm{C}$.

Thermal strain in samples $4^{\#}$ and $5^{\#}$ was zero before $40^{\circ} \mathrm{C}$ then reached approximately $6 \times 10^{-5}$ at $50^{\circ} \mathrm{C}$, followed by an almost linear increase to 0.01 and 0.009 at $400^{\circ} \mathrm{C}$. Samples $1^{\#}$ and $2^{\#}$ showed a slightly different change in thermal strain when subjected to identical temperature and triaxial stresses. These differences may be attributable to the different interior structure or intrinsic properties rather than stress; for example, rocks typically show some differences in axial compressive strength even if they are taken from the same block of rock. With these considerations, all the mudstone samples exhibited thermal expansion and showed almost the same change within $400^{\circ} \mathrm{C}$.
Two stages of thermal deformation were evident: first, very little thermal expansion RT $-50^{\circ} \mathrm{C}$; second, high thermal expansion at $50-400^{\circ} \mathrm{C}$. All samples except sample $2^{\#}$ exhibited stepwise thermal strain at temperatures up to $400^{\circ} \mathrm{C}$ : steps at $50-65^{\circ} \mathrm{C}$ and at $100-135^{\circ} \mathrm{C}$ in sample $1^{\#}$; at $150-175^{\circ} \mathrm{C}$ in sample $3^{\#}$; and at $300-320^{\circ} \mathrm{C}$ in sample $4^{\#}$. This may be attributed to the equilibration of the closure of microcracks and/or the generation of new microcracks.

A linear thermal expansion coefficient was obtained for each sample at different temperatures by fitting the observed axial thermal strain to temperature. For example, by fitting the axial thermal strain data to temperature from $50^{\circ} \mathrm{C}$ to $100^{\circ} \mathrm{C}$ and obtaining the average linear thermal expansion coefficient at $50-100^{\circ} \mathrm{C}$. This was considered to be the linear thermal expansion coefficient at $100^{\circ} \mathrm{C}$. In this way, the linear thermal expansion coefficient was obtained for increasing temperature (Figure 5).

Figure 5 demonstrates that mudstone had a very low linear thermal expansion coefficient at temperatures below $50^{\circ} \mathrm{C}$. The values for samples $1^{\#}-4^{\#}$ at $50^{\circ} \mathrm{C}$ were $3.74 \times 10^{-6} \cdot{ }^{\circ} \mathrm{C}^{-1}, \quad 1.42 \times 10^{-6} \cdot{ }^{\circ} \mathrm{C}^{-1}, \quad 1.11 \times 10^{-6} \cdot{ }^{\circ} \mathrm{C}^{-1,}$ and $2.26 \times 10^{-6} \cdot{ }^{\circ} \mathrm{C}^{-1}$, respectively. The coefficient fluctuated within the range $2.6-4.3 \times 10^{-5} \cdot{ }^{\circ} \mathrm{C}^{-1}$ from $50^{\circ} \mathrm{C}$ to $400^{\circ} \mathrm{C}$, as shown in Figure 5. Sample $4^{\#}$ experienced a slight increase in thermal expansion coefficient from 150 to $400^{\circ} \mathrm{C}$, being $2.68 \times 10^{-5} \cdot{ }^{\circ} \mathrm{C}^{-1}$ at $150^{\circ} \mathrm{C}$ and $3.01 \times 10^{-5} \cdot{ }^{\circ} \mathrm{C}^{-1}$ at $400^{\circ} \mathrm{C}$. There was no significant increment with rising temperature. These results conflict with reports from previous studies, possibly attributable to the stress effect. This is discussed further below. The average values of the linear thermal expansion coefficient $\left(\beta_{\text {av }}\right)$ of the four samples at $100-400^{\circ} \mathrm{C}$ are given in Figure 5.

3.2. Effect of Stress on Thermal Deformation of Mudstone. As seen in Figure 5, no significant increment in the linear thermal expansion coefficient was observed between $50^{\circ} \mathrm{C}$ and $400^{\circ} \mathrm{C}$. Only sample $4^{\#}$ showed a slight increase above $150^{\circ} \mathrm{C}$, but the coefficient was $3.01 \times 10^{-5} .{ }^{\circ} \mathrm{C}^{-1}$ at $400^{\circ} \mathrm{C}$. The value approached the value at $100^{\circ} \mathrm{C} .\left(2.96 \times 10^{-5} .{ }^{\circ} \mathrm{C}^{-1}\right)$ From this, it was inferred that the thermal expansion coefficient of triaxially stressed mudstone exhibited no increasing trend from 100 to $400^{\circ} \mathrm{C}$.

For specimens subjected to different stresses, the stress has some impact on the linear thermal expansion coefficient. The coefficients at seven temperature points $(100,150,200$, $300,350,400^{\circ} \mathrm{C}$ ) were averaged using equation (1) to obtain the mean coefficient. The results are shown in Figure 5:

$$
\beta_{\mathrm{av}}=\frac{1}{n} \sum_{n=1}^{7} \beta_{n}
$$

where $\beta_{\mathrm{av}}$ is the average linear thermal expansion coefficient from 100 to $400^{\circ} \mathrm{C} ; n$ is the number of temperature points $(n=7$, for the temperatures of $100^{\circ} \mathrm{C}, 150^{\circ} \mathrm{C}, \ldots, 400^{\circ} \mathrm{C}$ ); and $\beta_{n}$ is the linear thermal expansion coefficient at each temperature point.

The average coefficients for samples $1^{\#}$ and $2^{\#}$ were $3.19 \times 10^{-5} \cdot{ }^{\circ} \mathrm{C}^{-1}$ and $3.61 \times 10^{-5} \cdot{ }^{\circ} \mathrm{C}^{-1}$. The average coefficients for samples $3^{\#}$ and $4^{\#}$ were $3.08 \times 10^{-5} \cdot{ }^{\circ} \mathrm{C}^{-1}$ and $2.83 \times 10^{-5} \cdot{ }^{\circ} \mathrm{C}^{-1}$, both less than for samples $1^{\#}$ and $2^{\#}$. The 


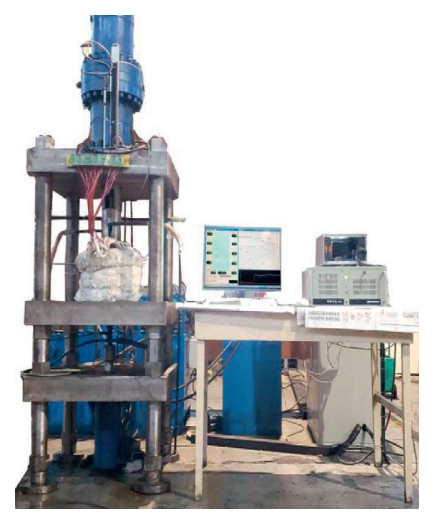

(a)

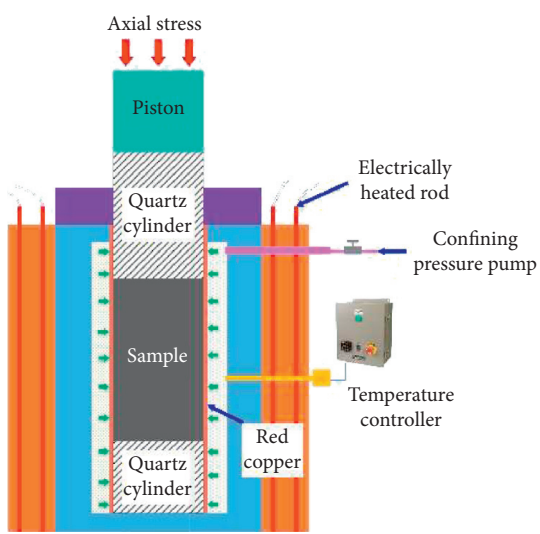

(b)

FIgURE 2: (a) Servocontrolled high-temperature test machine IMT-HTP100F. (b) Sample assembly.

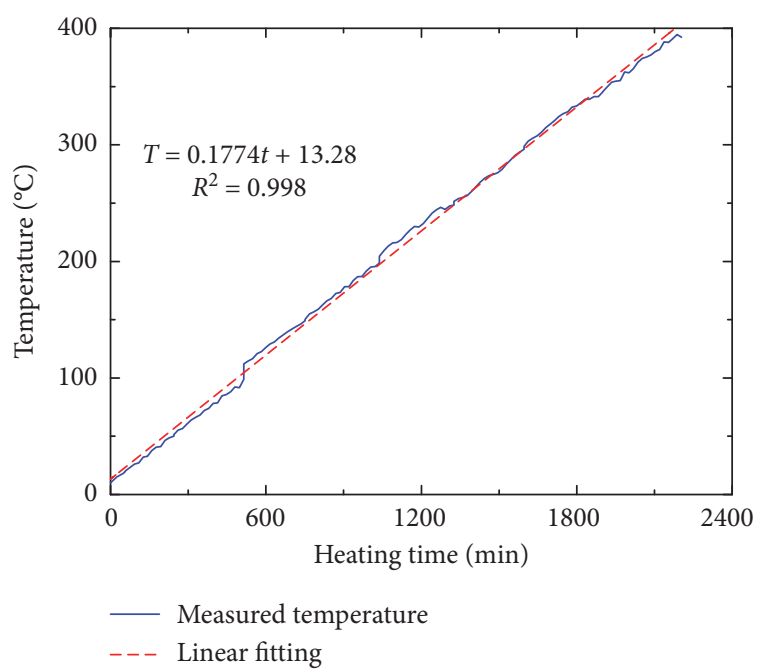

FIGURE 3: Heating rate of sample $1^{\#}$ recorded in the experiment.

TABLE 1: Testing conditions of all samples.

\begin{tabular}{lcccc}
\hline No & $\sigma_{\mathrm{a}}(\mathrm{MPa})$ & $\sigma_{\mathrm{c}}(\mathrm{MPa})$ & $T_{\max }\left({ }^{\circ} \mathrm{C}\right)$ & Heating rate $\left({ }^{\circ} \mathrm{C} \cdot \mathrm{hr}^{-1}\right)$ \\
\hline $1^{\#}$ & 5 & 6 & 400 & 10 \\
$2^{\#}$ & 5 & 6 & 300 & 10 \\
$3^{\#}$ & 12 & 6 & 400 & 10 \\
$4^{\#}$ & 8 & 4 & 400 & 10 \\
\hline
\end{tabular}

temperature of the rock has affected thermal expansion in two ways: swelling of the rock matrix, and forming new microcracks. However, stress inhibits thermal expansion because of partial closure of newly formed microcracks and constraining thermal swelling of the rock matrix. In particular, the applied stress restricts the opening of microcracks at high temperature due to the softening of the rock matrix; hence, a smaller thermal expansion coefficient occurs in rock subjected to greater triaxial stress.

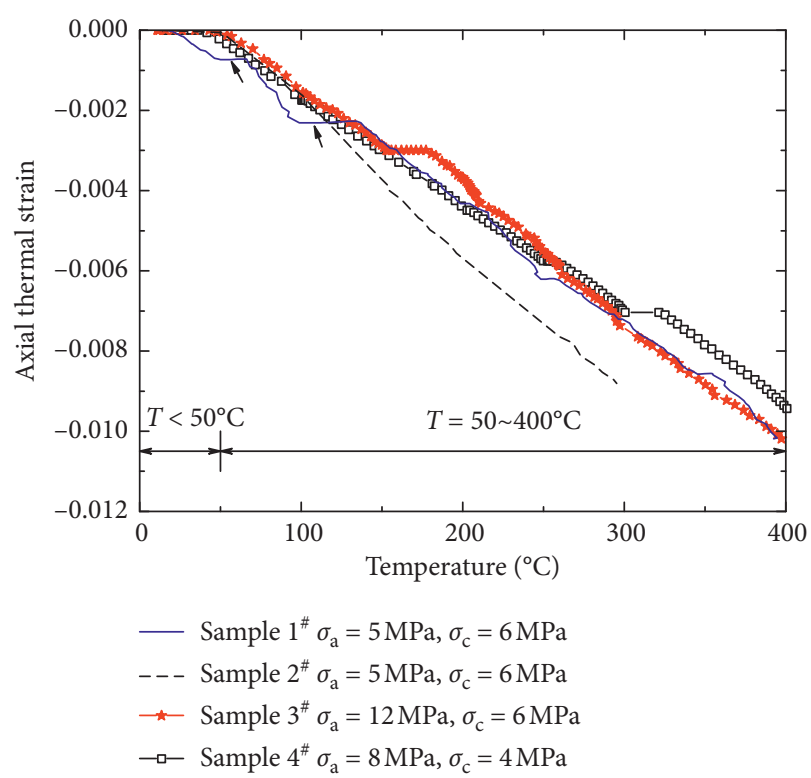

Figure 4: Axial thermal expansion of mudstone at $400^{\circ} \mathrm{C}$ vs. temperature.

3.3. Comparative Analysis of Thermal Expansion among Different Sedimentary Rocks. Mudstone is a very common sedimentary rock, which generally forms the roof and floor of oil and gas reservoirs and coal seams. Similarly, sandstone and limestone also overlie and underlie reservoirs of geological resources. All three types of rock may occur together and in close proximity to each other at the top and bottom of reservoirs. Hence, their different thermal expansions may be significant.

Figure 6 compares the thermal expansion of these three rock types. The sandstone was subjected to axial stress of 6.4 MPa [28]; the limestone was unconstrained [39] (see Table 2). Sandstone and limestone also exhibited linear thermal expansion from RT to $600^{\circ} \mathrm{C}$ with thermal expansion coefficients of $1.84 \times 10^{-5} \cdot{ }^{\circ} \mathrm{C}^{-1} \quad$ (sandstone) and 


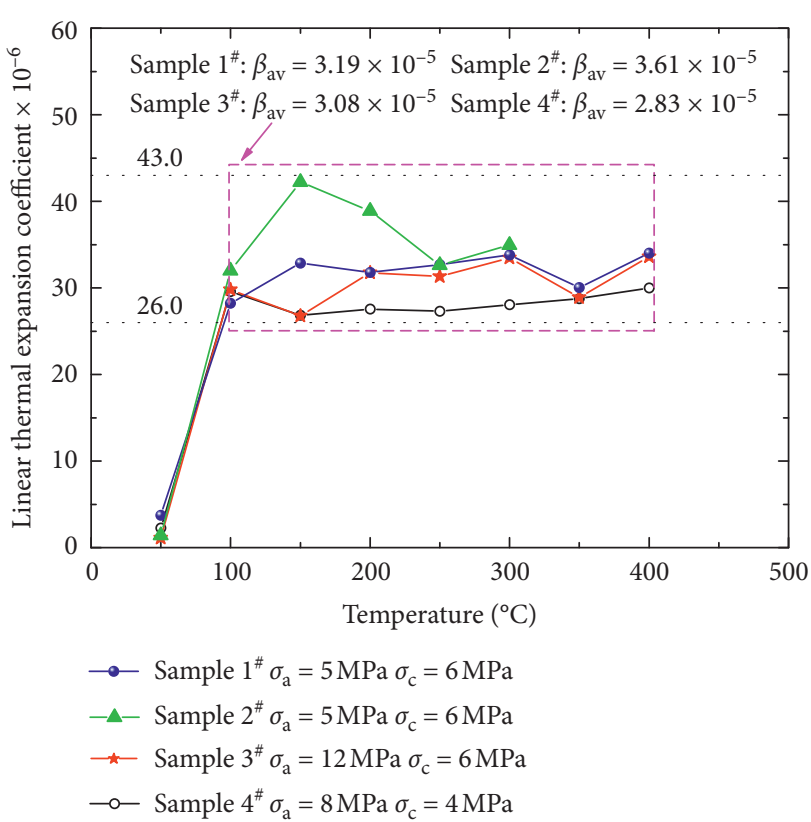

Figure 5: Linear thermal expansion coefficient of mudstone at high temperature and triaxial stresses.

$1.43 \times 10^{-6} \cdot{ }^{\circ} \mathrm{C}^{-1}$ (limestone), both lower than $3.19 \times 10^{-5} \cdot{ }^{\circ} \mathrm{C}^{-1}$ of $1^{\#}$ mudstone. Therefore, thermal expansion of these three sedimentary rocks appears to follow a rule that greater compressive strength (listed in Table 2) is related to less thermal expansion. The mechanism is explained by fundamental physics theory, discussed in detail in the following.

Figure 7 shows a model explaining the physical mechanism of thermal expansion of a solid. In the model, the position $R_{0}$ is the equilibrium distance where two atoms in the solid interact with each other. The initial position $(R=0)$ is assumed to be the position where atom $\mathrm{A}$ is located. The other atom $\mathrm{B}$ is located at position $\left(R=R_{0}\right)$. If we assume that atom $\mathrm{A}$ is immobile in a solid material, atom B will always vibrate with simple harmonic motion with a distance of $\delta$ about $R_{0}$ :

$$
\begin{aligned}
U\left(R_{0}+\delta\right)= & U\left(R_{0}\right)+\left(\frac{\partial U}{\partial R}\right)_{R_{0}} \cdot \delta+\frac{1}{2 !}\left(\frac{\partial^{2} U}{\partial R^{2}}\right)_{R_{0}} \\
& \cdot \delta^{2}+\frac{1}{3 !}\left(\frac{\partial^{3} U}{\partial R^{3}}\right)_{R_{0}} \cdot \delta^{3}+\cdots
\end{aligned}
$$

The potential energy of the motion is given by equation (2), generating the curve shown in Figure 8, which approximates a symmetrical curve about position $R_{0}$. Since $R_{0}$ is usually constant at room temperature, the solid does not exhibit thermal expansion. Upon heating, the motion of atom $\mathrm{B}$ at $R_{0}$ becomes nonharmonic and the equilibrium position moves towards the right-hand side of Figure 7 . The distance between atoms $\mathrm{A}$ and $\mathrm{B}$ exceeds $R_{0}$-that is, the solid expands. Generally, the interaction force between atom $\mathrm{A}$ and atom $\mathrm{B}$ significantly dominates the distance between the two atoms. The strong interactive force makes

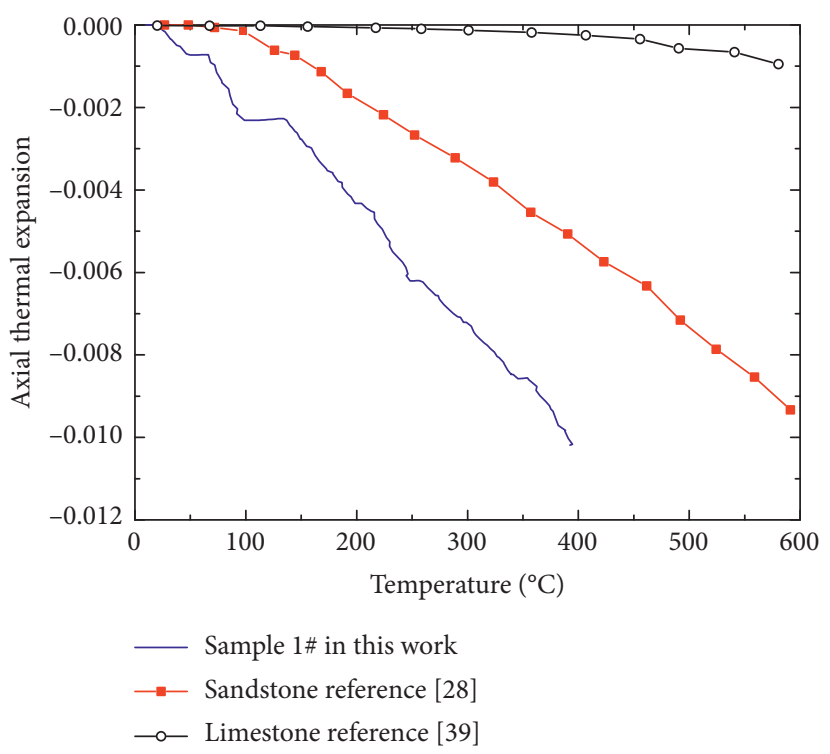

Figure 6: Comparison of axial thermal expansion for mudstone, sandstone, and limestone.

the atoms move closer to each other; that is, the distance between $A$ and $B$ is reduced. That means that atom B is harder to move towards the right in a solid with a stronger atomic interaction force: that is, solids with stronger atomic interaction force display smaller thermal expansion when heated.

The atomic forces are difficult to measure in a strong, brittle rock. However, it is positively related to the strength of the solid (e.g., uniaxial compressive strength [41]). Although mudstone, sandstone, and limestone are all sedimentary rocks, the differences in their mineral compositions are reflected in their different strengths, which are generally in the order $\sigma_{\text {mudstone }}<\sigma_{\text {sandstone }}<\sigma_{\text {limestone. }}$ The potential energy curves of adjacent atoms for the three types of rock during heating are shown in Figure 8. It is seen that the offset to the equilibrium position $\left(R_{0}\right)$ between two adjacent atoms of limestone is the smallest and the offset in mudstone is the largest. Hence, the linear thermal expansion coefficients of the three types of rocks are in the order $\beta_{\text {mudstone }}>\beta_{\text {sandstone }}>\beta_{\text {limestone }}$.

3.4. Effect of Porosity on Thermal Expansion of Rock. In fact, many factors have an influence on the thermal expansion of rock. These factors are the degree of bonding, the anisotropy of the grains, the size of the grains, and other factors. Porosity is an important parameter in rock. The previous study has shown that there is no effect of porosity on thermal expansion [42]. It can be explained by the physical model and mathematical model which was presented by Turner [43]. The physical model is seen in Figure 9. And the following equation can be used to describe the effect of different phases on thermal expansion:

$$
\alpha_{r}=\frac{\left(\alpha_{1} K_{1} F_{1} / \rho_{1}\right)+\left(\alpha_{2} K_{2} F_{2} / \rho_{2}\right)}{\left(K_{1} F_{1} / \rho_{1}\right)+\left(K_{2} F_{2} / \rho_{2}\right)},
$$


TABLE 2: Testing data for sandstone and limestone.

\begin{tabular}{lcccccccc}
\hline Sample & $\sigma_{\mathrm{a}}(\mathrm{MPa})$ & $\sigma_{\mathrm{c}}(\mathrm{MPa})$ & $T_{\max }\left({ }^{\circ} \mathrm{C}\right)$ & $D(\mathrm{~m})$ & $H(\mathrm{~mm})$ & UCS $(\mathrm{MPa})$ & Porosity $(\%)$ & Reference \\
\hline Sandstone & 6.4 & 0 & 800 & 20 & 50 & 56 & 4.4 & {$[28]$} \\
Limestone & 0 & 0 & 800 & 50 & 100 & 75 & 0.25 & {$[39]$} \\
Sample $1^{\#}$ & 5 & 6 & 400 & 50 & 100 & 43 & 2.1 & This work \\
\hline
\end{tabular}

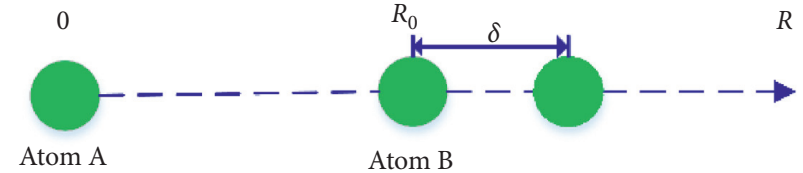

Figure 7: Physical model of thermal expansion of a solid [40].

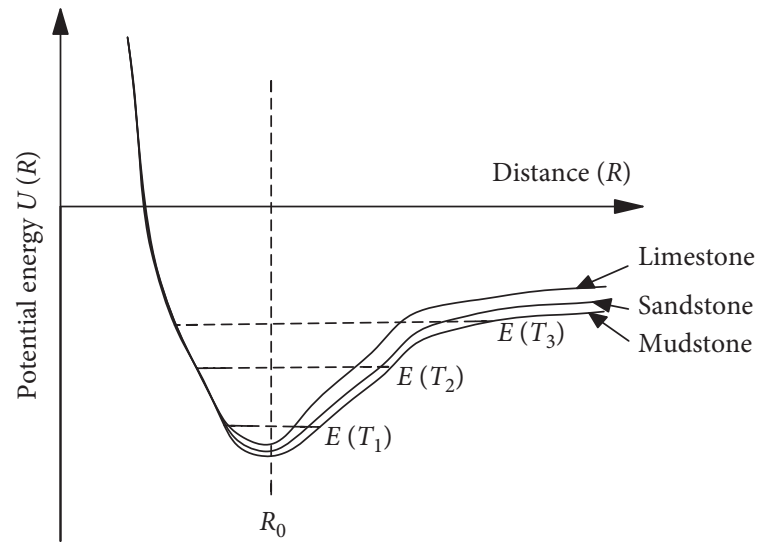

Figure 8: Potential energy of two interacting atoms in the thermal expansion of mudstone, sandstone, and limestone (modified after [40]).

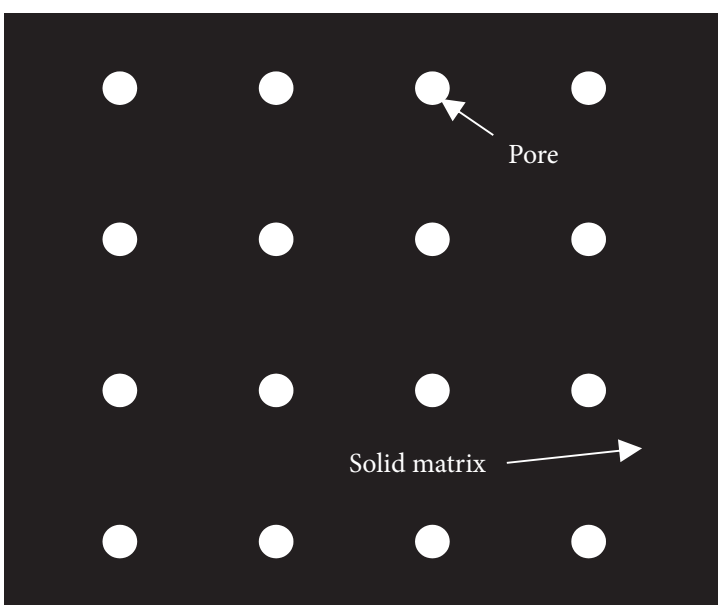

FIGURE 9: Schematic illustration of porosity [42].

where $\alpha_{r}$ was the coefficient of linear thermal expansion of rock; $\alpha_{1}$ and $\alpha_{2}$ were the coefficients of linear thermal expansion of phase 1 and phase 2; $K_{1}$ and $K_{2}$ denoted bulk modulus of phase 1 and phase 2; $F_{1}$ and $F_{2}$ represented mass fraction of phase 1 and phase 2; $\rho_{1}$ and $\rho_{2}$ were the density of phase 1 and phase 2. The parameters above the pores (phase 1) are far less than that of a solid matrix (phase 2). Equation (3) can be rewritten as follows:

$$
\alpha_{r}=\alpha_{2} .
$$

Hence, the thermal expansion of rock is exactly that of the matrix material.

\section{Conclusions}

The thermal expansion of mudstone was studied at temperatures up to $400^{\circ} \mathrm{C}$ and total triaxial stresses up to $24 \mathrm{MPa}$. The effect of temperature and stress on the linear thermal expansion coefficient was discussed. The differences between mudstone, sandstone, and limestone were also analyzed. The following conclusions are drawn:

(1) The mudstone demonstrated two distinct stages of thermal expansion when subjected to temperatures up to $400^{\circ} \mathrm{C}$. Very small thermal expansion with a linear thermal expansion coefficient of 1.11 to $3.74 \times 10^{-6} \cdot{ }^{\circ} \mathrm{C}^{-1}$ occurred below $50^{\circ} \mathrm{C}$, followed by an almost constant thermal expansion with the coefficient of 2.5 to $4.5 \times 10^{-5} .{ }^{\circ} \mathrm{C}^{-1}$ from $50^{\circ} \mathrm{C}$ to $400^{\circ} \mathrm{C}$. Hence, the linear thermal expansion coefficient of triaxially stressed mudstone did not increase with the temperature rising at $50^{\circ} \mathrm{C}$ to $400^{\circ} \mathrm{C}$.

(2) The application of triaxial stresses has the impact of both closing cracks and inhibiting grain expansion and swelling of the rock. Mudstone subjected to high triaxial stresses had a smaller linear thermal expansion coefficient than for low triaxial stresses.

(3) Thermal expansion is also related to rock type. A comparison with sandstone and limestone showed that mudstone had the largest linear thermal expansion coefficient (average $3.5 \times 10^{-5}{ }^{\circ} \mathrm{C}^{-1}$ ) and limestone exhibited the smallest $\left(1.43 \times 10^{-5} \cdot{ }^{\circ} \mathrm{C}^{-1}\right)$, with sandstone having an intermediate value $\left(1.84 \times 10^{-5} \cdot{ }^{\circ} \mathrm{C}^{-1}\right)$. Potential energy theory was used to explain the thermal expansion of the different rock types.

\section{Data Availability}

The data used to support the findings of this study have not been made available because the data are also part of another unpublished manuscript, which is a systematic research work.

\section{Conflicts of Interest}

The authors declare no conflicts of interest. 


\section{Acknowledgments}

This work was supported by the National Natural Science Foundation of China (Grant nos. U1810104 and 11772213), the Program for the Outstanding Innovative Teams of Higher Learning Institutions of Shanxi, and a research project supported by the Shanxi Scholarship Council of China (HGKY2019018).

\section{References}

[1] F. Torabi, N. Mosavat, and O. Zarivnyy, "Predicting heavy oil/ water relative permeability using modified corey-based correlations," Fuel, vol. 163, pp. 196-204, 2016.

[2] A. W. Bhutto, A. A. Bazmi, and G. Zahedi, "Underground coal gasification: from fundamentals to applications," Progress in Energy and Combustion Science, vol. 39, no. 1, pp. 189-214, 2013.

[3] C. D. Martin and R. Christiansson, "Estimating the potential for spalling around a deep nuclear waste repository in crystalline rock," International Journal of Rock Mechanics and Mining Sciences, vol. 46, no. 2, pp. 219-228, 2009.

[4] Z. Feng, Y. Zhao, A. Zhou, and N. Zhang, "Development program of hot dry rock geothermal resource in the Yangbajing basin of China," Renewable Energy, vol. 39, no. 1, pp. 490-495, 2012.

[5] W. G. P. Kumari, P. G. Ranjith, M. S. A. Perera, and B. K. Chen, "Experimental investigation of quenching effect on mechanical, microstructural and flow characteristics of reservoir rocks: thermal stimulation method for geothermal energy extraction," Journal of Petroleum Science and Engineering, vol. 162, pp. 419-433, 2018.

[6] Z. Zhong, D. Huang, Y. F. Zhang, and G. Ma, "Experimental study on the effects of unloading normal stress on shear mechanical behaviour of sandstone containing a parallel fissure pair," Rock Mechanics and Rock Engineering, vol. 53, no. 4, pp. 1647-1663, 2019.

[7] D. Huang, Y. Q. Li, Y. X. Song, Q. Xu, and X. J. Pei, "Insights into the catastrophic Xinmo rock avalanche in Maoxian county, China: combined effects of historical earthquakes and landslide amplification," Engineering Geology, vol. 258, Article ID 105158, 2019.

[8] D. M. Gu, D. Huang, H. L. Liu, W. G. Zhang, and X. C. Gao, "A DEM-based approach for modeling the evolution process of seepage-induced erosion in clayey sand," Acta Geotechnica, vol. 14, no. 6, pp. 1629-1641, 2019.

[9] F. Dong, Z. Feng, D. Yang et al., "Permeability evolution of pyrolytically-fractured oil shale under in situ conditions," Energies, vol. 11, no. 11, p. 3033, 2018.

[10] J. A. Zhao and L. Wang, "High-temperature mechanical properties of mudstone in the process of underground coal gasification," Rock Mechanics and Rock Engineering, vol. 44, no. 6, pp. 749-754, 2011.

[11] H. Tian, M. Ziegler, and T. Kempka, "Physical and mechanical behavior of claystone exposed to temperatures up to $1000^{\circ} \mathrm{C}$," International Journal of Rock Mechanics and Mining Sciences, vol. 70, pp. 144-153, 2014.

[12] K. Thirumalai and S. G. Demou, "Effect of reduced pressure on thermal-expansion behavior of rocks and its significance to thermal fragmentation," Journal of Applied Physics, vol. 41, no. 13 , pp. 5147-5151, 1970.
[13] T. P. Todd, Effect of cracks on elastic properties of low porosity rocks, Ph.D. thesis, Massachusetts Institute of Technology, Cambridge, MA, USA, 1973.

[14] D. Richter and G. Simmons, "Thermal expansion behavior of igneous rocks," International Journal of Rock Mechanics and Mining Sciences \& Geomechanics Abstracts, vol. 11, no. 10, pp. 403-411, 1974.

[15] H. W. Cooper and G. Simmons, "The effect of cracks on the thermal expansion of rocks," Earth and Planetary Science Letters, vol. 36, no. 3, pp. 404-412, 1977.

[16] Y. V. Ramana and L. P. Sarma, "Thermal expansion of a few Indian granitic rocks," Physics of the Earth and Planetary Interiors, vol. 22, no. 1, pp. 36-41, 1980.

[17] J. J. D. C. Lima and A. B. Paraguassu, "Linear thermal expansion of granitic rocks: influence of apparent porosity, grain size and quartz content," Bulletin Engineering Geology Environment, vol. 63, no. 3, pp. 215-220, 2004.

[18] V. Gräf, M. Jamek, A. Rohatsch et al., "Effects of thermalheating cycle treatment on thermal expansion behavior of different building stones," International Journal of Rock Mechanics and Mining Sciences, vol. 64, pp. 228-235, 2013.

[19] T. Tschegg and A. R. Mcbirney, "Properties of some common igneous rocks and their melts at high temperatures," Geological Society of America Bulletin, vol. 84, no. 11, pp. 35633592, 1973.

[20] P. G. Meredith, K. S. Knight, S. A. Boon et al., "The microscopic origin of thermal cracking in rocks: an investigation by simultaneous time-of-flight neutron diffraction and acoustic emission monitoring," Geophysical Research Letters, vol. 28, no. 10, pp. 2105-2108, 2001.

[21] J. Wood, P. Meredith, and A. Gudmundsson, "Coolingdominated cracking in thermally stressed volcanic rocks," Geophysical Research Letters, vol. 43, no. 16, pp. 8417-8425, 2016.

[22] L. Griffiths, O. Lengliné, M. J. Heap et al., "Thermal cracking in westerly granite monitored using direct wave velocity, coda wave interferometry, and acoustic emissions," Journal of Geophysical Research: Solid Earth, vol. 123, no. 3, pp. 22462261, 2018.

[23] J. T. Baud and T.-f. Wong, "Micromechanics of thermally induced cracking in three crustal rocks," Journal of Geophysical Research: Solid Earth, vol. 91, no. B12, pp. 1274312764, 1986.

[24] X. L. Xu and F. Gao, "Experimental study on the strength and deformation quality of granite with effect of high temperature," Applied Mechanics and Materials, vol. 226-228, pp. 1275-1278, 2012.

[25] E. Plevova, L. Vaculikova, A. Kozusnikova et al., "Thermal expansion behaviour of granites," Journal of Thermal Analysis and Calorimetry, vol. 123, no. 2, pp. 1555-1561, 2016.

[26] E. Plevová, L. Vaculíková, A. Kožušníková et al., “Thermal study of sandstones from different Czech localities," Journal of Thermal Analysis and Calorimetry, vol. 103, no. 3, pp. 835-843, 2011.

[27] P. W. J. Glover, P. Baud, M. Darot et al., " $\alpha / \beta$ phase transition in quartz monitored using acoustic emissions," Geophysical Journal International, vol. 120, no. 3, pp. 775-782, 1995.

[28] Z. G. Meredith and F. R. Tang, "Experimental study on thermal expansion coefficient changing rule of sandstone under high temperature," Journal of Mining and Safety Engineering, vol. 34, pp. 121-126, 2017.

[29] L. Zhang, X. Mao, M. Li, and R. Liu, "Experimental study of thermal expansion characteristics of coaly mudstone at high 
temperatures," Geotechnical and Geological Engineering, vol. 36, no. 1, pp. 521-529, 2018.

[30] F. E. W. Duvall, H. Y. Sohn, and C. H. Pitt, "Physical behavior of oil shale at various temperatures and compressive loads: 2 . Thermal expansion under various loads," Fuel, vol. 64, no. 2, pp. 184-188, 1985.

[31] Y. Wang, N. X. Sun, Y. Gao et al., "Thermal expansion characteristics of Huadian oil shale pyrolysis process," Journal of Engineering Thermophysics, vol. 38, pp. 124-130, 2017.

[32] Z. Feng, Y. Zhao, and Z. Wan, "Effect of temperature on deformation of triaxially stressed anthracite," Rock Mechanics and Rock Engineering, vol. 50, no. 4, pp. 1073-1078, 2017.

[33] Z. J. Feng, Y. S. Zhao, and Z. J. Wan, "Experiment study of the thermal deformation of in-situ gas coal," in Proceedings of the 2nd ISRM International Young Scholars' Symposium on Rock Mechanics, pp. 103-108, Beijing, China, October 2011.

[34] Y. S. Zhao, Z. J. Wan, Z. J. Feng, Z. H. Xu, and W. G. Liang, "Evolution of mechanical properties of granite at high temperature and high pressure," Geomechanics and Geophysics for Geo-Energy and Geo-Resources, vol. 3, no. 2, pp. 199-210, 2017.

[35] P. Zhao and Z. J. Feng, "Thermal deformation of granite under different temperature and pressure pathways," Advances in Materials Science and Engineering, vol. 2019, Article ID 7869804, 8 pages, 2019.

[36] S. J. Bauer and J. Handin, "Thermal expansion and cracking of three confined water-saturated igneous rocks to $800^{\circ} \mathrm{C}$," Rock Mechanics and Rock Engineering, vol. 16, no. 3, pp. 181-198, 1983.

[37] L. Pei, G. Blöcher, H. Milsch et al., “Thermal strain in a watersaturated limestone under hydrostatic and deviatoric stress states," Tectonophysics, vol. 688, pp. 49-64, 2016.

[38] C. Widhalm, E. Tschegg, and W. Eppensteiner, "Acoustic emission and anisotropic expansion when heating marble," Journal of Performance of Constructed Facilities, vol. 11, no. 1, pp. 35-40, 1997.

[39] H. B. Zhao and L. J. Yan, "Experimental study of thermal expansion property of limestone," Rock and Soil Mechanics, vol. 32, pp. 1725-1730, 2011.

[40] K. Huang, Solid Physics, Peking University Press, Beijing, China, 2014.

[41] H. S. Tsien, Physical Mechanics, Shanghai Jiao Tong University press, Shanghai, China, New Century Edition, 2007.

[42] J. B. Austin, "Thermal expansion of nonmetallic crystals," Journal of the American Ceramic Society, vol. 35, pp. 243-253, 1952.

[43] P. S. Turner, "Thermal-expansion stresses in reinforced plastics," Journal of Research of the National Bureau of Standards, vol. 37, pp. 239-250, 1946. 